\title{
Mutlak Ön Kabullerin Bilimi Olarak Metafizik: R. G. Collingwood ${ }^{1}$
}

Öz: R. G. Collingwood, metafiziği reddetmenin moda olduğu Çağdaş Felsefede, Aristoteles'e dönerek metafiziği yeniden yorumlamanın imkânını soruşturur. Bu soruşturma bağlamında metafizik, her türlü bilimsel ve entelektüel etkinliğin temelini olușturan mutlak ön kabullerin bilimidir. Mutlak ön kabul, bir dönemin paradigmasıdır. Mutlak ön kabul, doğruluğu sorgulanamayan fakat doğruluk ölçütünün mantıksal yeterliliğ̈idir. Collingwood'a göre mutlak ön kabuller tarihseldir ve onu analiz edecek olan metafiziğin de tarihsel olması gerekir. Tarihsel bir etkinlik olarak metafiziğin yöntemi de soru-yanıt mantığıdır. Metafizik, soru-yanıt mantığıyla mutlak ön kabulleri analiz eden evrensel bir bilimdir. Öte yandan metafizik, disiplinler-arası ilişkinin kurulmasında merkezi öneme sahiptir. Bu ilişsi her alanın kendi mutlak ön kabulleri arasında kurulacă̆ından metafizik etkinlik temeldir.

Anahtar Kelimeler: Bilim, Ön Kabul, Mutlak Ön Kabul, Metafizik, Soru-Yanıt Mantığı.

\section{Metaphysics as the Science of Absolute Presupposition: R. G. Collingwood}

Abstract: In Contemporary Philosophy, in which fashion rejection of metaphysics is fashionable, R. G. Collingwood investigates the possibility of returning to Aristotle and reinterpreting metaphysics. In the context of this investigation, metaphysics is the science of absolute presuppositions that form the basis of any scientific and intellectual activity. Absolute presupposition is the paradigm of a period. Absolute presupposition is the logical capability of the accuracy criterion that cannot be questioned. According to Collingwood, absolute presuppositions are historical, and metaphysics that will analyze it must be historical. Now the method of metaphysics as an historical activity embodies the logic of questioning and answering. Metaphysics is a universal science that analyzes absolute presuppositions by the logic questioning and answering. On the other hand, metaphysics

${ }^{1}$ Bu yazı, Çağdaş Felsefede Metafiziğin Yeniden Yorumlanması: R.G.Collinwood başlıklı yüksek lisans tezimden türetilmiștir. 
has a central role in establishing the interdisciplinary relationship. The metaphysical activity is essential since this relationship will be established between absolute presuppositions of each area.

Keywords: Science, Presupposition, Absolute Presupposition, Metaphysics, Questioning and Answering.

\section{Giriş}

Collingwood, An Essay On Metaphysics adlı eseri 20. yüzyılın ilk yarısında (1940) kaleme almıştır. Bu dönem, özellikle bütün dünyada Viyana Çevresinin daha baskın olduğu ve her kesimin metafiziğe karşı savaş açmış olduğu bir dönemdir. $\mathrm{Bu}$ dönem içinde pozitivist felsefe seküler bir dünya yaratma çabası kapsamında metafiziği topyekün reddetmeyi amaçlamıştır. Ortaçağdan itibaren metafizik, teoloji ile birlikte hatta özdeş olarak kullanıldığından teolojinin reddi metafiziğin de reddini doğurmuştur. Buna karşıllk Collingwood, bu özdeşliği aşarak metafiziği, tam da yaratılmak istenen seküler dünyanın ontolojik ve epistemolojik dayanağı olarak yeniden inşa etmeyi, eş deyişle; metafiziği yeniden felsefi etkinliğin merkezine yerleştirmeyi amaçlamaktadır. Bu amaç doğrultusunda Collingwood, An Essay on Metaphysics adlı eserde bizim metafizik olarak ifade ettiğimiz etkinliğin Aristoteles'te ne olduğunu ele alarak başlar. Collingwood'a göre Aristoteles bu etkinliği farklı isimlerle adlandırmaktadır. Birincisi, ilk felsefedir

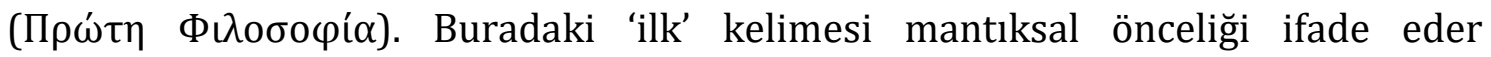

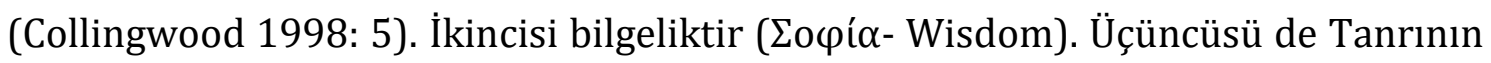

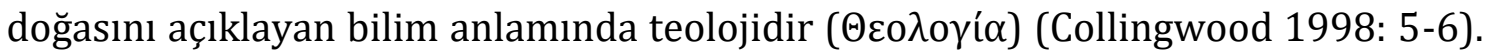
Collingwood, bu farklı adlandırmaları, her biri metafiziğin bir tanımı olabilecek iki yorumla sinırlandırır. Birincisi, Saf Varlığ ${ }^{2}$ ele alan ontolojik ve teolojik inceleme olarak metafiziktir. İkincisi de özel bilimlerin altında yatan ilk ilkelerin bilimi olarak metafiziktir (Collingwood 1998: 11). Collingwood, metafizik etkinliğin "ne”liğini ortaya koymak için Aristoteles felsefesine dönerken metafiziğin ikinci

2 Collingwood, 'Saf Varlık' (Collingwood 1998: 11-16) kavramını, Aristoteles'in 'varlık olmak bakımından varlık' (Aristoteles 1996: 187-189) kavramının karşılığı olarak kullanır. 
anlamını, yani ilk ilkelerin bilimi anlamını öne çlkararak metafiziği 'mutlak ön kabullerin' bilimi olarak ele almıştır. "Ben bunu söylerken metafiziğin mutlak ön kabullerin bilimi olduğunu ileri sürüyorum. Çünkü metafiziği bulan kişi olan Aristoteles'te gördüğüm şey budur. Ya da başka şekilde ifade edersek Aristoteles, metafiziğin ne olduğuna ilişkin açlklamalarında gördüğüm şey budur" (Collingwood 1998: 41). Bu bağlamda metafizik, hem belli bir dönemde yaşayan insanların temel inançlarını bulmak için girişilen bir araştırma hem de başka dönemlerde yaşamış insanların temel aldıkları mutlak ön kabullerin tarihsel olarak nasıl başka bir dizi ön varsayıma dönüştüğünü inceleyen bir etkinliktir. Metafiziğe ilişkin bu iki özellik bir yandan metafiziğin mutlak ön kabullerin bilimi olduğunu diğer yandan tarihsel bir bilim olduğunu bize göstermektedir. Dolayısıyla metafizik ön kabuller mantıksal ve tarihsel analize dayanmalıdır (Collingwood 1998: 49).

Collingwood metafiziğinin Aristoteles metafiziğinden en önemli farkı metafiziği tarihsel bir bilim olarak ele almasıdır. Collingwood'a göre Aristoteles, metafiziğin mutlak ön kabullerin bilimi olduğunu gayet iyi biliyordu. Fakat öte yandan "Aristoteles, salt varlıkla ilgili verimsiz (sonuçsuz) bir araştırma başlatmaktan ve salt bir varlık bilimi (a science of pure being) ve mutlak ön kabuller biliminin tek ve aynı şey olduğunu ileri sürmekten sorumludur" (Collingwood 1998: 49). Collingwood metafiziği salt bir varlık bilimi olarak ele almayı ve dolayısıyla bu ele alış ile mutlak ön kabullerin bilimi olarak metafiziğin bir ve yanı şey olduğu kabulünü reddeder (Collingwood 1998: 17). Collingwood'a göre metafizik, mutlak ön kabullerin bilimidir (Collingwood 1998: 41). Mutlak ön kabuller tarihsel olması itibariyle, onu inceleyecek metafizik bilimi de tarihseldir. Tarihsel olmayan her türlü metafizik yaklaşım dogmatik metafiziğe dönüşeceğinden metafiziksel, felsefi ve bilimsel soruşturmalara zarar verir. Collingwood, metafiziği felsefi düşüncenin merkezine yerleştirmeyi amaçlarken, kendi döneminde metafiziğin reddini kendilerine düstur edinen Viyana Çevresiyle hesaplaşır. Collingwood, An Essay On Metaphisiycs adlı eserin ikinci bölümünde Metafizik Karşıtığı başlığı altında hem "Metafizik karşıtlığı nedir?" sorusunu 
soruşturur hem de metafizik karşıtı tutum olarak "pozitivist metafiziği" inceler (Collingwood 1998: 143-154).

Collingwood, Metafizik kavramının Aristotelesçi bilimi ifade edip etmediğini soruşturur. "Aristotelesçi bir bilim için metafizik, Aristoteles'in adlandırması

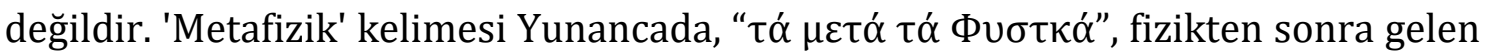
(kitaplar) anlamına gelir; ve bu kelime Aristoteles'in kendisi tarafindan kullanılmamıştır" (Collingwood 1998: 3-4). Aristoteles eserlerinin yerini ifade eden bir kavram nasıl olur da Aristotelesçi bilimin merkezine yerleşir. Collingwood'a göre; "Aristoteles çalışanlarından biri tarafından taşınmış bir başlık olarak 'metafizik', bir bilimin adlandırması değil, bir kitabın adlandırmasıdır. Onun modern kullanımdaki karşılığı Düzlem Trigonometrisi ya da Türlerin Kökeni gibi bir başlık değil fakat "Derleme" gibi bir başlıktır" (Collingwood 1998: 3-4). Bu başlığın ifade ettiği etkinlik de özel bir etkinliktir ve kelimeyi o özel etkinliğin içinde kullanmak gerekir. Bu bağlamda Metafizik kelimesini birebir çevirip 'fizik

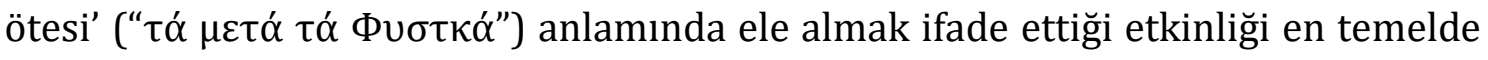
yanlış anlamaktır. Collingwood'a göre metafizik, özel bir alana ait bilimsel etkinliğin genel adıdır. Örneğin, biz nasıl ki "müzik salonu" ya da "spor salonu" dediğimizde evin bir odası olan salonu anlamıyorsak 'metafizik' dediğimizde de bu

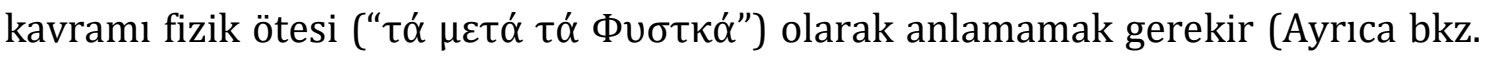
Collingwood 1998: 3). Metafizik özel bir etkinliği ifade eder ve bu etkinlik günümüze kadar iki farklı tanım üzerinden şekillenmiştir.

\footnotetext{
Birincisi, en temel kavramların mantıksal bir araștırması olarak metafiziktir. İkincisi de en temel varlık ya da varlıkların ontolojik araştırması olarak metafiziktir. Birinci tanım çağdaş analitik filozoflar tarafından çokça benimsenmiştir. İkinci görüș ise tarih boyunca da yaygın bir biçimde benimsenmiş ve günümüzde ders giriş kitaplarında sık sık bahsedilen bir görüş olmuștur (White 1987: 30).
}

Collingwood varlıkların ontolojik araştırmasının bir uzantısı olarak 'fizik ötesi' anlamı eleştirmekle beraber 'fizik ötesi' anlamındaki metafiziği "dogmatik metafizik" olarak görmektedir. Dogmatik metafizik tutum, metafizik etkinliği ifade etmemekle birlikte metafiziğe ilişkin bulanıklığın da kaynağı olmuştur. 
Collingwood, metafiziğe ilişkin bulanıklığın ortadan kaldırılması ve metafiziğin yeniden tesis edilmesi için metafizik karşıtı tutumları değerli görmüş ve onlarla hesaplaşmayı kendine görev edinmiştir (Collingwood 1998: 81-82). Bu hesaplaşmanın en büyük muhatabı da pozitivist felsefenin temsilcileri olmuştur. Collingwood, özellikle realist tutumun temsilcisi olarak gördüğü pozitivistleri ve onların metafiziğe karşı olan tutumlarını eleştiri süzgecinden geçirmiştir. Bu bağlamda metafizik karşıtı tutum üçe ayrılır. Birincisi metafizik problemini belirli noktalarda ilerleten metafizik karşıtı tutumdur. İkincisi metafiziğe tepki olsun diye metafizik karşıtı tutumu temel alan yaklaşımdır. Üçüncüsü de metafiziğe rasyonel olarak değil de irrasyonel olarak karşı çıkan tutumdur (Collingwood 1998: 82-83). $\mathrm{Bu}$ sinıflamadan hareketle Collingwood'un metafizik karşıtı tutumu tamamen metafiziğe zarar veren bir tutum olarak görmediğini, aksine metafiziği yeniden sorgulamanın yolunu açan ilerici yanlarının olabileceğini iddia edebiliriz.

Metafiziği yeniden tesis etmek klasik felsefeyi de yeniden tesis etmek demektir. Dolayısıyla Collingwood'un metafiziğe ilişkin düşünceleri ile felsefenin ne olduğuna ilişkin düşünceleri birbirine paraleldir. Metafiziğin itibarını iade etmek aynı zamanda felsefenin de itibarını iade etmek demektir. Metafiziği dogmatik metafizikten, felsefeyi de pozitivist felsefeden ayırmak metafiziği yeniden inşa etmek için gereklidir. Klasik felsefeyi yeniden tesis etmek ne anlama gelmektedir? Klasik felsefeyi yeniden tesis etmek "Felsefe Nedir?" sorusunu yeniden ele almak, felsefenin klasik tanımını yeniden hatırlamaktır. Collingwood'a göre;

\footnotetext{
Felsefenin geçerli iki tanımı vardır. İlk olarak o, düşüncenin kendi üzerine çevrilmesi, dışsal bir nesneyi düşünmeyi bırakıp, kendinin böyle bir nesnenin farkına varması sürecini inceleyen düşünce olarak görülür: düşünce kendinin bilincinde olur. İkinci olarak, düşüncenin kendisini eleştirilmeyen sinırlardan kurtarması, geçerli nedenlere dayanmayan hiçbir şeye inanmamaya kararlı bir girişim, bütün doğmalardan, varsayımlardan ya da görüşlerden vazgeçmek ve tamamen akılcı bilgi idealinin kovalaması olarak görülür (Collingwood 2014: 224).
}

Felsefeye ilişkin bu iki tanımdan birincisi felsefenin refleksif (düşünce üzerine düşünmek) özelliğine; ikincisi de inter-disipliner (disiplinler arası) düşünce 
özelliğine gönderimde bulunur. Bu iki tanım felsefenin hem nesnesini hem de yöntemini ifade eder. Bu bağlamda refleksif düşünce, felsefenin öz-eleştirel yanını, inter-disipliner düşünce ise felsefenin eleştirel yöntemini temsil eder. Eleştiri ve öz-eleştiri yetisini kaybetmiş bir felsefe dogmalara dönüşür. Metafizik düşüncenin bir dogmaya dönüşmesi ve dogmalar ortaya koymaya başlaması da felsefenin bu iki yetiyi kaybetmesiyle ilişkilendirilebilir. Felsefe, kendi içine kapalı ve kendini eleştiri, öz-eleştiri yetisinden muaf tutunca fildişi kulelerinde gerçekleşen bir dogma etkinliğine dönüşür. Collingwood'a göre 19. yüzyılda felsefeciler ve doğa bilimcileri her biri ötekinin işini az bilen ve ötekinin işine az ilgi duyan meslek öbeklerine dönüşmüştür. "İki tarafa da zarar veren bir modadır bu ve iki tarafta da bunun sona erişini görmeye, yarattığı iletişimsizlik uçurumuna köprü kurmaya yönelik derin bir istek vardır. Köprüye her iki ucundan başlanması gerekir"(Collingwood 1999: 11-12). Collingwood'un felsefi incelemeleri ve metafizik çözümlemeleri böyle bir inter-disipliner bağın kurulmasına hizmet eder. Zira inter-disipliner bakış, aslında, her disipline ait mutlak ön kabullerin birbiriyle temas etmesidir. Çünkü metafizik, herhangi bir özel bilimin mutlak ön kabullerini değil, her özel bilimin mutlak ön kabullerini ortaya koyarak benzer ve farklı yanlarını gözler önüne sermeyi amaçlar. Metafizik, mutlak ön kabulleri ortaya koyarken felsefe bu ortaya koyma etkinliğine eşlik etmekle beraber onları yargılama yetkisine/yetisine de sahiptir (Coşkun 2011: 560). Bu bağlamda metafizik ile felsefe arasında şöyle bir ilişki kurulabilir. Her metafizik düşünme felsefi olmak zorundadır. Ancak her felsefi düşünme metafizik olmak zorunda değildir. Bu ilişkide felsefe, metafiziği de kapsayan bir düşünme etkinliğidir. Bu düşünme etkinliği, mutlak ön kabulleri de dönüştürme yetkisine/yetisine sahip olduğu için bu mutlak ön kabuller üzerine kurulu toplumsal yapıları da dönüştürme yetkisine/yetisine sahiptir. Dolayısıyla felsefe, hem toplumsal hem de dönüştürücü bir etkinliktir. Toparlarsak felsefe, refleksif, eleştirel, sistematik, dolayısıyla metodolojik, içsel bir düşünme etkinliğidir (Coşkun 2011: 556-557). 


\section{Soru Yanıt Mantığında Ön Kabulün Yeri}

Collingwood, düşünme etkinliği olarak ele aldığı felsefenin yöntemini "soruyanıt" olarak ortaya koyar (Collingwood 1996: 34). Collingwood'un kullandığı "Soru" kavramı "Metafizik" kavramı gibi mesleki bir kavramdır. Soru kavramı ile günlük hayatta sorduğumuz genel, rastgele, sıradan sorular değil, nedensel ilişkilere dayalı sistemli ve düzenli bir düşüncenin ürünü olan sorular kastedilmektedir (Collingwood 1996: 35). Bir şeyin kesin bir soru olması onun "mantıksal etkisi"ne bağlıdır (Collingwood 1996: 27, White 1987: 132-133). Bir ön kabulün mantıksal etkisi ön kabulün doğru olmasına değil sadece varsayılmış olmasına dayanır (Collingwood 1996: 39). 0 halde her soru belli bir düşünceyi temsil eder. Her ne kadar düşünceleri dile getirmeye çalışsak da dile getiremediğimiz ama üzerine düşündüğümüz bir sürü şey vardır. Dile gelen düşünceyi dile geldiği şekliyle, dile gelemeyen düşünceyi de bir metafizik analiz aracılı̆̆ıyla ortaya koyarız. Collingwood'a göre, bizim ileri sürdüğümüz her soru, belli bir probleme yöneliktir. Bu problem, dile getirebildiğimiz düşünce alanına ait olduğu gibi dile getiremediğimiz düşünce alanına da ait olabilir. Hem günlük hayatta rastgele sorduğumuz sorular hem de sistemli ve düzenli düşünmeyi temsil eden felsefi, bilimsel ve metafizik soruları önceleyen belli ön kabuller kümesi vardır. Soru ile o soruya ilişkin mümkün yanıt kümesi arasında da öncelik-sonralık ilişkisi vardır. Nasıl ki ön kabuller soruları hem zamansal hem de mantıksal olarak öncelerse, sorular da yanıtları hem zamansal hem de mantıksal olarak önceler. "Bir soru mantıksal olarak yanıtını önceler. Düşünce, bilimsel olarak düzenlendiğinde, bu mantıksal önceliğe geçici öncelik eşlik eder. İlk önce soru biçimlendirilir ardından soruya yanıt aranmaya başlanır." (Collingwood 1998: 24-25). Eş deyişle, her soru belli bir ön kabul kümesini içerir. Eğer soru ile ön kabul arasındaki ilişki doğrudan ilişkiyse o sorunun dayandığı ön kabul tektir. Eğer soru ile ön kabul arasındaki ilişki dolaylı bir ilişkiyse o sorunun dayandığı ön kabul birden çok olabilir. Bu durumda o sorunun yanıtı dolaylı olarak başka sorularının da yanıtı 
olabilir. Belli bir sorunun yanıtı ile o belli sorunun "doğru" yanıtı aynı şey değildir. Bir sorunun mümkün yanıt kümesini, sorunun dayandığı ön kabul belirler. Ancak bir sorunun doğru yanıtını "mutlak ön kabul" belirler. Dolayısıyla, bir yanıtın doğruluğunun birinci ölçütü yanıtın muhatabı olan sorudur. İkinci ölçütü de sorunun dayandığı mutlak ön kabuldür.

Bir sorunun doğru yanıtının ölçütü neden ön kabul değil de mutlak ön kabuldür? Ön kabulün sorunun doğru yanıtının ölçütü olamamasının nedeni ön kabulün yapısıyla ilgilidir. Collingwood'a göre ön kabul mutlak olabildiği gibi göreceli de olabilir (Collingwood 1998: 29). Göreceli ön kabul, doğru ya da yanlış olabilen ancak neyin doğru ya da yanlış olabileceğini belirleyemez. Mutlak ön kabul ise doğru ya da yanlış olamayan ancak neyin doğru ya da yanlış olabileceğini belirleyebilen bir yapıya sahiptir (Collingwood 1998: 31). Ön kabulün niteliği bir sorunun doğruluğunun ölçütü değil, o sorunun anlaşılabilir olmasının ölçütüdür. Eğer biz bir ön kabulün doğru olup olmadığını soruşturuyorsak, soruşturduğumuz ön kabulün "mutlak" değil "göreceli” ön kabul olduğunu gösterir. Göreceli ön kabuller olgusal olarak sınanabildiği için doğru ya da yanlış olabilirken; mutlak ön kabuller mantıksal referanslara dayandığı için doğru ya da yanlış olamazlar. Biz, mutlak ön kabule dayanarak bir sorunun hatta göreceli bir ön kabulün doğru ya da yanlış olabilirliğini sınayabilir ve soruşturabiliriz. Sonuç olarak Collingwood'un ön kabullere ilişkin düşüncelerini altı önermede toplayabiliriz: “1. İleri sürülen her önerme bir soruya yanıttır. 2. Her soru belirli ön kabul(ler)e dayanır. 3. Bir ön kabulün mantıksal etkisi sadece varsayılmış olmasına dayanır. 4. Bir ön kabul göreceli ya da mutlak olabilir. 5. Ön kabul doğru ya da yanlış olabilen önermelerdir. 6. Mutlak ön kabuller önermeler değildir” (Uygun 2014: 79-80).

\section{Mutlak Ön Kabullerin Bilimi Olarak Metafizik}

Mutlak ön kabul nasıl doğruluğu sorgulanamayan ancak doğruluğun ölçütü olabilmektedir? Bu sorunun yanıtı mutlak ön kabulün yapısında saklıdır. Mutlak ön kabuller mantıksal analize dayanır. "Mantıksal analiz ise, mutlak ön kabulün ne 
olduğuna yönelik bir analizdir. Ve bu analiz ancak, düşünce analizi ile açıklanabilir" (Connelly 2003: 89). Her düşünce analizi mutlak ön kabulün ne olduğuna ilişkin bir analiz midir? Collingwood, mutlak ön kabullerin mantıksal yapısını ve ne olduğunu ortaya koyan düşünce analizini metafizik analiz olarak tanımlamaktadır (Collingwood 1998: 45-47). Ve bu metafizik analiz yüksek seviyeli düşünme biçimini ifade eder (Collingwood 1998: 36). Düşük seviyeli düşünme biçimi sadece duyusal olanla sınırlı kalan düşünmedir. Sıkı düşünme ya da yüksek seviyeli düşünme duyusal alanı reddetmeyen ya da küçümsemeyen fakat bu duyusal alanla sınırlı kalmayan zihinsel etkinliktir (Collingwood 1998: 36). Collingwood düşük seviyeli düşünce tarzına örnek olarak realizmi ve onun uzantısı olarak gördüğü pozitivist felsefeyi verir (Collingwood 1998: 34-35). Realizm ve pozitivist felsefenin düşük seviyeli düşünme biçimi olarak ele alınmasının nedeni bilginin kaynağını beş duyu organına indirgeyip var olan şeyleri onlardan ibaret saymasıdır. Collingwood'a göre bu ilkel epistemolojiyi eleştirmek ile pozitivist epistemolojiyi eleștirmek birdir (Collingwood 1998: 35). Öte yandan böyle düşük seviyeli bir düşünme tarzından ve bilgi kuramından hareketle herhangi bir metafizik soruşturma mümkün değildir. Çünkü bu düşünme biçimi bir ön kabule dayandığının dahi farkında değildir. Dolayısıyla ilgilendiği sorunun da belli bir ön kabule dayandığının farkında değildir. $\mathrm{Bu}$ nedenle bu düşünme biçimlerinden metafizik hakkında herhangi bir sorgulama beklememek gerekir. Bu kuramlar, sadece yanıta odaklı düşük seviyeli düşünme biçimidir. Öyleyse, bu düşünme biçimi ne yanıtın arkasındaki soruları ne de soruların arkasındaki mutlak ön kabulleri kavrayabilir.

Düşük seviyeli düşünme ile yüksek seviyeli düşünme arasındaki farkı bu iki düşünme biçiminin bilimsel etkinliğe bakışı üzerinden de ele alabiliriz. Düşük seviyeli düşünme bilimi salt deneysel bir etkinlik olarak görürken, yüksek seviyeli düşünme bilimi kuramsal bir etkinlik olarak kavrayacaktır. Bu ayrım bize Fransız bilim tarihçisi ve düşünürü Emilé Meyerson'un yasalı-nedensel bilim ayrımını hatırlatmaktadır. "Yasalı bilim" değişeni "nedensel bilim" ise değişmeyeni inceler. 
Bu bağlamda yasalı bilim nedensel bilimin üzerinde inşa edilir. Eş deyişle nedensel bilim yasalı bilimin ontolojik dayanağıdır. Meyerson'da ise ontoloji, "bir anlamda gözlem ilişkilerini anlamak için gerekli olan ve altta duran temel dayanaklara karşılık gelir. İşte, "ilişki" ve "temel dayanak" arasındaki ayırımın kaynağı, aklın iki temel ilkesi olan yasalılık ve nedenselliktir" (Kabadayı 2009: 165). Bu bağlamda yüksek seviyeli düşünmeyi ve nedensel bilimi temsil eden mutlak ön kabullerin bilimi olarak metafizik, bilim yapabilmemizin mantıksal ve ontolojik dayanağıdır. Collingwood, çağdaş felsefe içinde metafiziği yeniden yorumlarken bu iki etkinlik arasındaki sıkı ilişkinin kopmuş olduğunun farkındadır. Hatta Collingwood, bu kopuşu savunanların popüler olduğu bir dönemde ve onların hegemonyası altında bu iki etkinliği yeniden ele almayı amaçlamaktadır (Collingwood 1998: 41). Ancak Collingwood, bilim ve metafizik etkinliği kendi anladı̆̆ı ve kabul ettiği anlamıyla ele almaktadır. Collingwood'a göre bilim, bir konu üzerinde düzenli ve sistemli düşünme işidir (Collingwood 1998: 4). Metafizik, mutlak ön kabuller üzerine düzenli ve sistemli düşünmedir (Collingwood 1998: 65). Dolayısıyla bu iki etkinlik alanının yeniden yorumlanması ve arasındaki köprünün kurulması mutlak ön kabulün mantıksal yapısını ortaya konulmasıyla mümkündür.

Yüksek seviyeli düşünme ile düşük seviyeli düşünme biçimi arasındaki ayrımı soru-yanıt mantığı üzerinden de düşünebiliriz. Düşük seviyeli düşünme yanıtlara odaklanırken yüksek seviyeli düşünme sorulara odaklanır. Bir felsefi etkinlik olarak metafizik, yanıtları değil yanıtların arkasındaki soruları, hatta soruların arkasındaki mutlak ön kabulleri inceler. Metafizik etkinliği soru sormak, merak etmek üzerinden tanımladığımızda metafizik etkinliğin mutlak ön kabulünü "yanıt" merkezli dogmatik hakikatten "soru" merkezli eleştirel etkinliğe çekmiş oluruz. Bu eksen değişikliği metafizik etkinliğin yolunu bulması için yeterli değildir. Bununla birlikte yüksek seviyeli hakiki soruları düşük seviyeli sahte sorulardan ayıklamak gerekir. "Bir soruyu ortaya atmaya ya da ortaya çıkarmaya neden olan güç mantıksal yeterliliktir. (...)Sorudan soruya düşünme süreci her bir sorunun doğru yanıtlanmasına değil, onların sadece yanıtlanmasına bağlıdır" 
(Collingwood 1998: 39). Bu noktada ortaya çıkan temel problem gerçek soruları sahte sorulardan nasıl ayıklayacağımızdır. Bu ayıklama verilen yanıtlar üzerinden gerçekleşemez. Çünkü soruyu soru yapan "yanıt” değil "mantıksal yeterlilik”tir. Dolayısıyla hakiki soruları sahte sorulardan ayıklamak, sorunun mutlak ön kabule ya da göreceli ön kabule dayandığının açığa çıkarılmasıdır. Özetlersek, mutlak ön kabuller, yüksek seviyeli düşünme biçiminin ürünü olan hakiki soruların altında yatan ön kabullerdir. Her bir yanıt bir soruyla ve her bir soru da mutlak ön kabulle ilgilidir. Bu nedenle biz bir soruya yanıt verirken verdiğimiz yanıtın doğruluğu ya da yanlışlığı düşük seviyeli soruların dayandığı göreceli ön kabule değil yüksek seviyeli hakiki soruların dayandığı mutlak ön kabule bağlıdır. Dolayısıyla bir yanıtı doğru ya da yanlış kılan mutlak ön kabuldür. Collingwood'a göre mutlak ön kabuller doğru ya da yanlış olan ön kabuller değildir. Aksine, mutlak ön kabuller bir önermenin doğru ya da yanlış olmasını mümkün kılan mantıksal referanstır. Diğer bütün önermeler ve önermelere ilişkin değerlendirmeler bu mantıksal zemin üzerine bina edildiği için Collingwood asıl olarak mutlak ön kabullerle ilgilenmiştir (Collingwood 1998: 31-32, Ayr. Bkz. White 1987: 134).

Mutlak ön kabuller mantıksal olarak doğruluğu kanıtlanamaz. Fakat her türlü kanıtlamanın ilk ilkelerini oluştururlar. Bu durumda, mutlak ön kabullerin ispatını talep edebilir miyiz? Ya da "ne hakla" mutlak ön kabullerin ispatı istenebilir? Mutlak ön kabullerin ispatını istemek, mutlak ön kabullerin mantıksal ve ontolojik doğasına aykırıdır. Zaten mutlak ön kabullerin ne olduğunu bilen kişi bu ispatın ne kadar boş olduğunu da bilir ve kanıtlama ihtiyacı duymaz. Ancak buna rağmen bunu kanıtlayana kadar sizin söylediğiniz bizi ilgilendirmiyor düşüncesini taşıyanlara karşı Collingwood'un yanıtı şu olmuştur: “Gelgelelim bunu soran kişi kuşku duyduğu şeyin ne olduğunu biliyor mu? Yani kanıtlarsam kanıtladığım şeyin o olduğunu nasıl bileceksin? Mutlak ön kabuller doğru ya da yanlış olabilen şeyler olmadıkları için onların ispatını istemek, istenilen şeyin ne olduğunu bilmemektir" (Collingwood 1998: 41). Çünkü birileri mutlak ön kabulleri ispatlamaya kalktığında, kullanacağı ontolojik ve mantıksal referans yine mutlak ön kabullerin 
kendileri olacaktır. Bu noktayı daha da açığa kavuşturmak için aklın en temel ilkesi olan "özdeşlik" ilkesini örnek alalım. Özdeşlik ilkesi kanıtlanmayan ancak aklın diğer ilkelerini kanıtlamak için kullanılan ilk ilkedir. 'Çelişmezlik' ve 'Üçüncü Halin Olanaksızlığg’ ilkeleri özdeşlik ilkesinden hareketle türetilir (Ayrıca bkz. Heimsoeth 2007: 48-60). Özdeşlik ilkesini ispatlamaya kalktığımızda başvuracağımız ilkenin kendisi yine 'özdeşlik' ilkesi olmayacak mı? O halde özdeşlik ilkesi mantık biliminde doğru ya da yanlış olmayan ancak her türlü doğru ve yanlışın ölçütünü belirleyen mutlak ön kabuldür. Bu bağlamda sorulması gereken şey mutlak ön kabullerin ispatı değil mutlak ön kabullerin nasıl irdelenip açığa kavuşturulması gerektiğidir.

Mutlak ön kabullerin açığa kavuşturulması analiz ile mümkündür. Ancak bu analiz, Viyana Çevresinin ileri sürdüğü salt önermelerin mantıksal analizi değil, önermelerin de altında yatan ve mantıksal olarak önermeleri önceleyen mutlak ön kabullerin açığa çıkarılmasıdır. 0 halde analiz, göreceli ön kabullerin değil mutlak ön kabullerin açığa kavuşturulmasında metafizik bir rol oynar (Coşkun 2011: 564565). Collingwood, aldığı eğitim nedeniyle mutlak ön kabulleri hazır olarak edinmiş ve işinde uzman olan, ancak metafiziğe ve metafizik etkinliğe yapancı kişileri ya hazır edindiği mutlak ön kabulleri temellendirmeye, metafiziksel analizini yapmaya, ya da terk etmeye davet eder. Analizi yapan kişi eğer yaptığı işin farkındaysa bu davete icabet edecektir. Ancak kişi yaptığı iş üzerine hiç düşünmemişse söz konusu göreceli ön kabuller olduğunda kimi değişimleri kabul ederken iş mutlak ön kabullere gelince saldırgan bir tutum içine girecektir (Collingwood 1998: 84-90). Herhangi bir kişiyle (bilim insanı, politikacı, felsefeci...) tartışırken eğer hiddetlenip saldırganlaşıyorsa, bilin ki o kişinin mutlak ön kabullerine dokunmaya başlamışsınızdır. Kişinin göreceli ön kabule gösterdiği tepkinin mutlak ön kabule gösterdiği tepkiden farklıdır. Bunun nedeni göreceli ön kabul ile mutlak ön kabulün üstlendiği roldür. Göreceli ön kabuller, insanlara pratik olarak kısa vadede gerekli olan ön kabullerdir. Bu nedenle insan bu ön kabullere tam olarak bağlanmaz; dolayısıyla, bu tür ön kabulleri terk etmesi daha 
kolaydır. Mutlak ön kabuller ise bütün eylemlerin, araştırmaların temelinde yattığı için, bunların terk edilmesi ya da sorgulanması çok zordur. Dolayısıyla mutlak ön kabuller kişinin değiştirmekte zorlandığı ve onların sarsılması kendi durduğu zeminin sarsılması anlamına gelen en temel referans noktalarıdır.

Nasıl ki ön kabulleri göreceli ön kabul ve mutlak ön kabul olarak ikiye ayırdıysak, bunlara yönelik analiz etkinliğini de ikiye ayırabiliriz. Bu ayrıma göre göreceli ön kabulü temel alan analiz, Aristoteles'in bilimler sinıflamasında özel bilim olarak adlandırdığı sıradan bilimsel analizdir. "Sıradan bilimde göreceli ön kabuller bir sepete konulur ve ondan sonra da sorular sorulmaya başlanır. Böylece sıradan bilim inceleme işinde göreceli ön kabulleri öne çıkarırken mutlak ön kabulleri geriye atar" (Collingwood 1998: 45). Mutlak ön kabulü temel alan analiz de, Aristoteles'in evrensel bilim olarak adlandırdığı metafizik analizdir. "Metafizik, inceleme işinde mutlak ön kabulleri ön plana çlkarırken, göreceli ön kabulleri arkaya atar. Metafizik, mutlak ön kabulleri sepete koyma işine girişir" ( Collingwood 1998: 45). Mutlak ön kabulleri analiz etmenin arkasında onları temellendirme kaygısı yatmaz. Onlar üzerine düzenli ve sistemli biçimde düşünme kaygısı yatar. Ve bu metafizik temelli kaygı bilimsel ve felsefi temellere sahiptir. Bu bağlamda sıradan bilimsel etkinlik ile evrensel bilimsel etkinlik arasındaki ayrımı yeniden düşünebiliriz. Bu durumda sıradan bilimsel etkinlik bağını metafizik etkinlikten kopararak sadece göreceli ön kabullerle ilgilenirken; evrensel bilim, metafizikle olan bağını güçlendirerek mutlak ön kabullerle ilgilenir. Toparlarsak, bilim bir şey üzerine düzenli ve sistemli düşünme etkinliği iken; metafizik mutlak ön kabuller üzerine düzenli ve sistemli düşünme etkinliğidir. "(...) metafizik, bu ya da şu düşünme kırıntısı ya da parçasının gidişinde, bu ya da şu grup ya da grupların, bu ya da şu kişilerin ortaya koyduğu mutlak ön kabullerin ne olduğunu anlama çabasıdır" (Collingwood 1998: 47). Metafizikçinin mutlak ön kabullerin ne olduğunu anlama çabasına onların evrensel olmaları eşlik eder. Mutlak ön kabuller evrensel iken, göreceli ön kabuller evrenselleşmeye çalışan yerel kabullerdir. Mutlak ön kabullerin evrensel oluşu içsel kapsayıcılığına dayanır. Bu nedenledir ki 
göreceli ön kabuller hiçbir şekilde mutlak ön kabullerin yerine kullanılamaz ve birbiriyle örtüștürülemez. Bu iki ön kabul iki farklı bilimsel etkinliğin analiz incelemesine tabidir.

Mutlak ön kabullerin en temel özelliklerini șu şekilde özetleyebiliriz. Mutlak ön kabuller, soru-yanıt yönteminde yanıtlarla ilgili değil soruların ön kabulüyle ilgilidir. Mutlak ön kabullerin değeri olgusal olarak sınanabilirliğiyle ya da doğrulanabilirliğiyle değil, mantıksal işleviyle ölçülür. Mutlak ön kabuller, bir dönemin kavram çerçevesini belirleyen toplumsal, ontolojik ve mantıksal dayanaklardır. Mutlak ön kabuller kișiden kişiye değișen kabuller değil nesnel ve evrensel ön kabullerdir. Mutlak ön kabuller, bir toplumun miras olarak bıraktığı ve o mirasın herkes tarafından benimsendiği ön kabullerdir. Dolayısıyla mutlak ön kabuller tarihseldir (Coşkun 2011: 564). Ve tarihsel olan bu kabulleri inceleyecek analiz edecek metafizik etkinliğin kendisi de tarihsel olmalıdır.

\section{Tarihsel Bir Bilim Olarak Metafizik}

Metafizik etkinliğin ortaya koyduğu her soru mutlak ön kabullere dayanan ve mutlak ön kabullerin doğasını sorușturan bir sorudur. Collingwood An Essay On Metaphysics adlı eserde mutlak ön kabullerin doğasını soruştururken, onların tarihsel olduğunu vurgular. Mutlak ön kabullerin tarihselliğini açıklamak için de nedensellik ile yasa ayrımına başvurur. Örneğin, "Newtoncu fizikte, fizik dünyada bazı olayların nedeni olduğu bazılarının ise olmadığı varsayılır; (...) Nedenlerin işlemediği durumlarda, söz konusu olayların yasaların işlemesinden dolayı olduğu varsayılır" (Collingwood 1998: 49). Buna göre, bir nedenden dolayı meydana gelmiş olay ile bir yasadan dolayı meydana gelmiş olay arasında da ayrım yapılır. Bu ayrımı benzer şekilde yirminci yüzyıl düşünürü Emile Meyerson da ele almıştır. Meyerson bir nedenden dolayı meydana gelmiş olay ile bir yasadan dolayı meydana gelmiş olay ayrımını yasalı bilim ile nedensel bilim kavramlarıyla karşılamaktadır. 'Yasalı' bilim betimsel bir karaktere sahip iken 'nedensel' bilim açıklayıcı bir karaktere sahiptir. Eş deyişle, "Yasalı bilim, olguları betimleyen, 
tahmin eden; bunları yöneten ilişki ve işlemlere göndermede bulunan bilimsel yasalara karşılık gelir" (Kabadayı 2011: 58). Ki doğa yasası, aynı koşullar sağlandığında aynı olguların her yerde ve her zaman aynı sonuçları doğuracağı kabulünü içerir. Buna karşılık "nedensel bilim, betimleyici bilimin keşfettiği yasaları açıklama işine girişir. [...] Yasalılık ve nedensellik insanın doğayı yorumlamasında rol oynayan iki önemli ilkedir ve keşfedilmemişlerdir; peşinen varsayılırlar" (Kabadayı 2011: 58). Peşinen varsayılan bu yasalılık ve nedensellik durumunun varsayılma süreci tarihseldir. $\mathrm{Bu}$ da her dönemin kendine özgü varsaydığı ilkelerin olduğunu gösterir. Bu ilkeleri ortaya çıkaracak etkinlik, sıradan bilimin icra ettiği özel bilim değil evrensel bilimin icra ettiği metafiziktir. Metafizik, her dönemde ortaya çıkmış mutlak ön kabulleri ve ön kabulleri tarihsel olarak inceleyen bir etkinliktir. 'Neden' kavramı üzerinden bu tarihsel incelemeyi örneklendirebiliriz. “On dokuzuncu yüzyılda genel olarak bilim insanları tarafından yapılan farklı bir ön kabulle karşılaşıyoruz. Buna göre bütün olayların nedenleri vardır" (Collingwood 1998: 50). Newtoncu fizikte ileri sürülen yasanın da yerini neden almıştır. Newtoncu fizikten sonra Kant fiziğine bakacak olursak; "Kant fiziğinin özgünlüğü şudur ki, Kant fiziği neden kavramı ile yasa kavramı birbirlerinin yerine geçecek şekilde kullanır" (Collingwood 1998: 50). Arkasından modern fizik gelir. "Modern fizikte neden kavramı ortadan kalkmıştır. Nedenlere göre hiçbir şey olup bitmez. Nedenlerden dolayı da hiçbir şey meydana gelmez" (Collingwood 1998: 50). Tarihsel olarak her dönemin kendi mutlak ön kabulleri vardır. Bu mutlak ön kabulleri gözler önüne serecek olan metafizik analizdir. Bu bağlamda Newtoncu fiziğin mutlak ön kabulü "Bazı olayların nedeni vardır" şeklinde iken, Kantçı düşüncede "Bütün olayların nedeni vardır" şeklindedir. Einstein fiziğinde neden kavramı ortadan kalkarak "Herhangi bir olayın nedeni yoktur" mutlak ön kabulüne dönüşmüştür. Bu önermeler "fizik biliminin üç farklı okulunda sırasıyla ortaya konmuş belli mutlak ön kabullerdir. Bunları oluşturan bilim için bunların her biri temel olarak önemlidir. Çünkü bunların her biri o bilimin yapısını, o bilim içerisinde sorulacak soruları ve bunlara verilecek olanaklı 
cevapları belirliyor" (Collingwood 1998: 52). Mutlak ön kabullerdeki bu dönüşümden hareketle bir problemin metafizik bir problem olması ile tarihsel bir problem olması aynı anlama gelmektedir. Ancak bu ilişkiyi tersten kuramayız. Eş deyişle her metafizik problemin tarihsel olduğunu söyleyebiliriz, ancak her tarihsel problemin metafizik problem olduğunu söyleyemeyiz.

Mutlak ön kabulleri ortaya çıkarmak, onların ne olduğunu bilmek değildir. Çünkü mutlak ön kabullerin bilgisini ileri sürmek metafizikçinin değil mantıkçının işidir (Collingwood 1998: 48). Metafizikçi, Aristoteles gibi, o çağda hangi mutlak ön kabullerin kullanıldığını bulur. Metafizikçi bu mutlak ön kabulleri tarihsel olarak ortaya çıkarırken onların doğru ya da yanlış, iyi ya da kötü olduklarıyla ilgilenmez. Bunlarla ilgilenecek olan bilim insanlarıdır. Ya da metafizikçi doğru ya da yanlışla ilgilenirken bu ilgilenme etkinliğini metafizik etkinlik olarak görmez. Metafizikçi de doğru ya da yanlış üzerine düşünür ve bir şeyin doğru ya da yanlış olduğunu belirtir. Fakat doğru ya da yanlış dediği şeyin mutlak ön kabul değil göreceli bir ön kabul olduğunu bilir (Collingwood 1996: 32). Çünkü mutlak ön kabuller doğru ya da yanlış olan önermeler değildir. Mutlak ön kabuller bizim bir şeye doğru ya da yanlış dememizi mümkün kılan mantıksal dayanaklardır. Sonuç olarak, biz onlara doğru ya da yanlış demeyiz onlara dayanarak bir şeye doğru ya da yanlış deriz.

Metafizik analizin belirli bir mutlak ön kabule yönelik olup olmadığını nasıl anlayabiliriz? Collingwood'a göre bunu bilmenin yolu o düşünce sisteminin kayıtlarına bakmaktır (Collingwood 1996: 60). Belli bir sistemin kayıtları da o sistemin dışa vurduğu düşüncedir. Buradaki kayıtlar en geniş anlamda bir uygarlığın ortaya koyduğu bütün ürünlerdir. Dolayısıyla, bir düşünce sistemini anlamanın yolu sistemin kendisini doğrudan ya da dolaylı olarak dışa vurmasına bağlıdır. Eğer bir düşünce sistemi kendini doğrudan ya da dolaylı olarak dışa vurmamışsa ne o sistemin mutlak ön kabulleri ortaya konulabilir ne de o düşünce sistemi ve o dönem aydınlatılabilir. Çünkü metafizik inceleme bir düşünce sisteminin niyetini değil kayıtlarını incelemektir. Bu açıdan metafizikçinin işi ile 
arkeoloğun işi benzerdir. Arkeolog nasıl ki bir dönemi aydınlatmak için o döneme ait kayıtlara bakıyorsa (Collingwood 1996: 25-26-30), metafizikçi de bir dönemin mutlak ön kabullerini aydınlatmak için o döneme ait kayıtlara bakar. Mutlak ön kabulleri ortaya koyduktan sonra diğer bilim insanları ile birlikte o dönemi anlamaya ve aydınlatmaya başlar. Çünkü metafizikçi, belirli bir dönemde ortaya çıkmış mutlak ön kabullerin doğruluğuyla ya da yanlışlığıyla değil ortaya çıkışıyla ilgilenir.

\section{Sonuç}

Çağımızda metafiziğe ilişkin problemlerin bir kısmı metafizikçilerden kaynaklanırken bir kısmı da bizim metafiziği kavrayış tarzımızdan kaynaklanmaktadır. Metafiziği kavrayış tarzımızdaki en önemli problemlerden birisi de metafiziği tarihsel bir bilim olarak kavrayamamış olmamızdır. Metafiziği tarihsel bir bilim olarak kavrayamamış olmamızın temel nedenlerinden birisi bizdeki tarih algısının yüzyıllardır hatalı olarak yerleşmiş olmasıdır. Collingwood'a göre insanlar arasında tarihe ilişkin yaygın görüş şöyleydi: "Tarih geçmişle ilgili yapılan ve hâlihazırda yazılı eserlerde ve tarihçinin böyle inandı̆̆ı için otorite kabul ettiği kişilerin iki dudağının arasında bulunan ifadelerin tekrarıdır" (Collingwood 1998: 58). Böyle bir tarih algısının ne metafiziğin ne de düşüncenin tarihselliğiyle bir ilgisi vardır. Tarihsel düşüncenin doğasını kavramış insanlar zaten metafiziğin tarihsel bir bilim olduğunu anlar. Bu insanların ikna edilmeye değil, 'metafizik tarihsel bir bilimdir' ifadesini anlamasına ve kavramasına ihtiyaç vardır. Collingwood'a göre eğer biri bu ifadeyi kavrayamıyor ve metafiziğin tarihsel olduğunu anlayamıyorsa demek ki tarihi kes-yapıştır tarihi olarak görüyor. “Tarihçinin bazı sınırlamalar içinde kendi geliştirdiği yorumlarla süslemeye izinli olduğu hazır ifadelerin bu tekrarına ben kes-yapıştır tarih diyorum: bu sözdeki 'tarih' kelimesi 'yanlış bir şekilde adlandırılmış tarih' anlamına gelmektedir” (Collingwood 1998: 58). Collingwood, 'metafizik tarihseldir' dediğinde kullandığı 'tarih' kelimesi kes-yapıștır tarih algısı değil belli bir bilimsel eserde hangi mutlak 
ön kabullerin kullanıldığını analiz eden metafizikçinin bakış açısıdır. Bu bağlamda tarih, kes-yapıştır edimi değil, yorumlama ve analiz edimidir. Kes-yapıştır yönteminde tarihçinin tarihe katacağı hiçbir şey yoktur. Böyle bir tarihçilik tarihsel perspektifi geliştirmek yerine onu tekrar eder. Bu nedenle bir tarihçi olarak metafizikçi, kendini tekrar eden bir tarihsel perspektifle değil, dinamik ve geliştirici bir tarihsel perspektifle metafizik inceleme yapabilir. Metafiziğin tarihsel bir bilim oluşu kes-yapıştır tarihle değil, mutlak ön kabullerin tarihselliğiyle mümkündür.

Metafizikçi ile tarihçi arasında bir ilişki var mı? Metafizik tarihsel bir bilimdir dediğimizde, metafizik analizin de tarihsel olduğunu söylemiş oluruz. Tarihçi nasıl ki kayıtlara kafasında belli bir soru, problem ile yaklaşırsa metafizikçi de zihninde belli bir soru, problem ile mutlak ön kabullere yaklaşır. Ve mutlak ön kabuller ışığında zihnindeki soruyu, problemi yorumlamaya, analiz etmeye ve çözümlemeye çalışır. Bu çözümleme kanıtlar üzerinden yürür. Collingwood'a göre kes-yapıştır yöntemine dayanan tarih otoritelerin beyanına dayanarak oluşturulmuş kayıtlardan ibarettir. Bu otorite, dönemin mevcut politik gücü de olabilir. Tarih, işleyişini topladığı kanıtlardan otoritenin beyanına kaydırdığında hem otonomisini hem de güvenilirliğini kaybedecektir. Tarihsel perspektifi yeniden kurmak ise tarihi, tarihin dışındaki her türlü otoriteden ayrı düşünmektir. Tarihi kendi otonom yapısı içinde düşünmektir. Bu kavrayış, aynı zamanda, mutlak ön kabullerin bilimi olan metafiziği de otonom kılar.

Çağımızda metafiziği yeniden düşünmek, metafizik etkinliğin otonomisi temelinde onu reform etmektir. Bu girişimin iki temel aşaması vardır. Birincisi, metafiziğe ilişkin bulanıklığın ortadan kaldırılmasıdır. İkincisi de metafiziğin kapsam alanının belirlenmesidir. Metafiziğe ilişkin en önemli bulanıklık ise onun tarihsel bir etkinlik olarak görülmemesidir. Collingwood'a göre metafiziğin tarihsel bir etkinlik olarak görülememesinin en büyük sorumlusu Aristoteles'tir. “Aristoteles yaratmakta olduğu bilimin mutlak ön kabullerin bilimi olduğunu gayet 
iyi biliyordu. Ve onun Metafizik adlı eseri bilimin kesinliği ile ilgili ve çıkarımlarının farkına vardığı kavrayış ile ilgili birçok kanıt taşır" (Collingwood 1998: 61). Metafiziğe ilişkin mutlak ön kabullerin bilimi ve saf varlığın bilimi anlamlarının birbirine indirgenebilir olduğunu düşünmek, metafiziğin ne olduğuna ilişkin derin bir problemi başlatmıştır. Metafiziğin ne olduğu problemi onu temsil edecek kişinin nasıl bir etkinlik içinde olacağı karmaşasını da doğurmuştur. Buna bağlı olarak; "Orta Çağ’da metafizikçinin öncül eğitiminin başlıca mantıktan; on yedinci yüzyılda fizikten; on dokuzuncu yüzyılda psikolojiden oluşması kabul edilmekteydi" (Collingwood 1998: 61). Bu farklılık metafizik etkinliğin neyi kapsayacağı probleminin bir sonucudur.

Aristoteles'te ilk kes sistematik olarak tanımlanan ve Ortaçağ dolayımıyla günümüze taşınan 'metafizik etkinlik'in kapsam alanı 'fizik ötesi' alanıyla sınırlandırılmıştır. Metafiziği sadece fizik ötesi anlamıyla ele almak metafiziğe ilişkin hem bulanıklığın hem de kapsam alanı probleminin kaynağıdır. Metafizik etkinliğin tarihsel olduğunu gözler önüne serdiğimizde, metafizik etkinliğin fizik ötesi etkinlikten tarihsel etkinliğe çekmiş oluruz. 0 halde metafizik etkinliğin tarihselliğini tesis etmek, yüzyıllardır süregelen fizik ötesi anlamından koparmaktır. "Aristoteles bize milattan önce dördüncü yüzyıl Yunan biliminin mutlak ön kabullerini açlklar; St. Thomas Orta Çağ Avrupa bilimininkilerin; Spinoza on yedinci yüzyıl Avrupa biliminkilerin ya da özel amacıyla alakalı olduğunu düşündüklerini açıklar" (Collingwood 1998: 71). Collingwood, metafizik etkinliğin tarihsel olduğunu ortaya koymakla birlikte tarihselliğin kendisini de yakın ve uzak tarih (milattan önce) olarak ikiye ayırır. Bu noktada sorulabilecek en temel soru tarihsel olarak metafizik etkinliği icra eden metafizikçi yakın tarihle mi, uzak tarihle (milattan önce) mi ilgilenir? Eş deyişle metafizikçi yakın tarihte ortaya çıkmış mutlak ön kabulleri mi, yoksa uzak tarihte (milattan önce) ortaya çıkmış mutlak ön kabulleri mi inceler? "Sadece yakın geçmişle meşgul olma alışkanlığı metafiziğin tarihsel bir bilim olduğunun keşfinden sonra ayakta kalamaz. Bu keşif, metafizik çalışmayı artık geçmişin en ufak giriş salonuna değil tamamına açarak 
metafizik çalışmanın kapsamını genişletmektedir" (Collingwood 1998: 71). Dolayısıyla metafizik etkinlik tarihin her aşamasına ve bu aşamalarda yapılmış her çalışmaya kapılarını açmak durumundadır. 


\title{
Metaphysics as the Science of Absolute Presupposition: R. G. Collingwood
}

\author{
Summary
}

\author{
Bahtiyar UYGUN \\ Ress. Assist. \\ Munzur University, Faculty of Letters, Department of Philosophy, Tunceli, TR \\ ORCID: 0000-0002-8393-5295 \\ bahtiyaruygun@munzur.edu.tr
}

Introduction

In Contemporary Philosophy where it is fashionable to refuse metaphysics, R. G. Collingwood inquires the possibility of reinterpret metaphysics. In the context of this inquiry, in his book titled An Essay on Metaphysics, Collingwood start discussion on what would be Aristotle equivalent of the activity we describe as metaphysics. Collingwood inquired whether the concept of Metaphysics describes Aristotelian science or not. It is not Aristotle's name for an Aristotelian science. The word

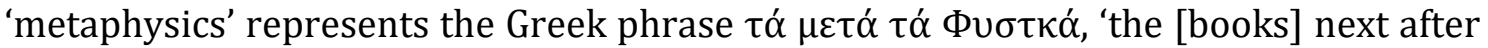
the Physics'; and this phrase was used not by Aristotle himself. (Collingwood 1998: 34). How would a concept defining place of Aristotelian works be placed at the center of Aristotelian science? According to Collingwood: "as a title borne by one of Aristotle's works, 'metaphysics' is not the name of a science. It is the name of a book" (Collingwood 1998: 4). This labeling refers to an exclusive activity and must be understood in the context of this exclusive activity. According to Collingwood, metaphysics is the general name of a scientific activity in a special area. For instance, just like how we do not think about hall that is a part of our houses upon mention of "music hall" or "sports hall", 'metaphysics' also must not be understood as beyond

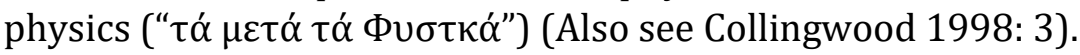

According to Collingwood, Aristotle describes this activity with various different

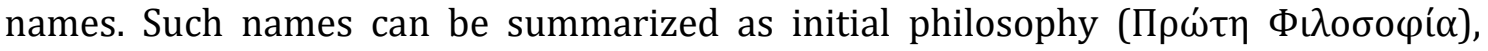

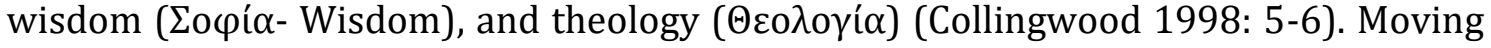
from such descriptions, two different comments of Collingwood on metaphysics come forward. The first is metaphysics as ontological and theological review discussing "Pure Being". The second is metaphysics as the science of initial firsts behind special sciences (Collingwood 1998: 11). Under "No Science of Pure Being" title of An Essay on Metaphysics, (Collingwood 1998: 11-17) Collingwood emphasizes metaphysics cannot be discussed as the science of pure being. Instead, he suggests that metaphysics would be discussed as the science of initial firsts behind special sciences. "In saying this I am assuming that metaphysics is the science of absolute presuppositions. (...) or rather, because it is what I find left in Aristotle's account of what metaphysics is, when 
something else which I have shown to be nonsensical has been removed" (Collingwood 1998: 41). Thus, reinterpreting metaphysics in Modern Philosophy is underlining the meaning of metaphysics as the science of absolute presuppositions instead of its 'beyond physics' meaning. This can be fulfilled by discussing metaphysical activity in philosophical activity. In this context, every metaphysical consideration is philosophical consideration. However, not all philosophical consideration is metaphysical consideration.

\section{The Place of Presupposition is Question Answer Logic}

According to Collingwood, the method of philosophical-metaphysical activity that would display logical structure of absolute presuppositions is "question-answer" logic (Collingwood 1996: 34). The concept of "Question" used by Collingwood is a professional concept just like the concept of "Metaphysics". The concept of question refers not to the general, random, ordinary questions we ask in daily life but the questions that are products of a systemic and regular thinking based on causal relationships (Collingwood 1996: 35). The fact that something is an absolute question is based on its "logical effect" (Collingwood 1996: 27, White 1987: 132-133). There is a definite presuppositions set prioritizing philosophical, scientific, and metaphysical questions representing both random questions we ask in daily life and systemic and regular thinking. That is, every question includes a definite presupposition set. In case the question and presupposition are directly related, there is a single presupposition based on that question. In case there is an indirect relationship between the question and presupposition, that question might be based on several presuppositions. In this case, answer of that question might indirectly be the answer to other questions. Answer of a question and the "correct" answer of that certain question is not the same thing. The possible answer set of a question is determined by the presupposition that question is based on. However, the correct answer of a question is determined by the "absolute presupposition". Thus, the first standard of the correctness of a response is the question that is the addressee of the answer. The second standard is the absolute presupposition the question is based on. The reason absolute presupposition, rather than presupposition is the standard of the correct answer of a question is related to the structure of presupposition. According to Collingwood, presupposition could be absolute as well as relative (Collingwood 1998: 29). Relative presupposition could be right or wrong but cannot determine what could be right or wrong. However, absolute presupposition has a structure that is not right or wrong but could determine what could be right or wrong (Collingwood 1998: 31). The quality of presupposition is not the standard of correctness of a question, but its comprehensibleness. Consequently, ideas of Collingwood related to presuppositions could be summarized in six propositions: "1. Every proposition is the answer to a question. 2. Every question is based on certain presupposition(s). 3. Logical effect of a presupposition is only based on its being assumed. 4. A presupposition could be relative or absolute. 5 . Presuppositions are propositions that could be right or wrong. 6. Absolute presuppositions are not propositions" (Uygun 2014: 79-80). 


\section{Metaphysics as the Science of Absolute Presuppositions}

What does Collingwood understand from absolute presupposition? According to Collingwood, absolute presupposition is the paradigm of a period. Absolute presupposition is the logical competence of labeling something whose rightness cannot be questioned as right, that is the measure of rightness. Absolute presuppositions cannot be logically proven right. However, they are the first principles of all kinds of proving. In this case, can we request proof of absolute presuppositions? Because absolute presuppositions are not things that could be right or wrong, requesting their proof is not knowing what is requested (Collingwood 1998: 41). When someone attempts at proving presuppositions, the ontological and logical reference used would once again be the absolute presuppositions themselves.

Absolute presuppositions could be clarified through analysis. Also this analysis is not the logical analysis of absolute propositions put forward by the Vienna Circle, but revelation of the absolute presuppositions lying behind and logically prioritizing propositions. Just like how we separated presuppositions into two as relative presupposition and absolute presupposition, we can also separate analysis activity towards them into two. The analysis based on relative presupposition based on this separation, "the relative presuppositions are put into the basket, (...) The absolute presuppositions are thrown back" (Collingwood 1998: 45). The analysis based on absolute presupposition, "the relative presuppositions that are thrown back, and the absolute presuppositions that are put into the basket" (Collingwood 1998: 45). Analysis of absolute presuppositions does not have the concern with justification. While absolute presuppositions are universal, relative presuppositions are local presuppositions that attempt at universalizing. Universalism of absolute presuppositions is based on their internal comprehensiveness.

Basic properties of absolute presuppositions could be summarized as the following. Absolute presuppositions are not related to answers in question-answer method, but presuppositions of questions. Value of absolute presuppositions could be measures not by their factual testability, but by their logical function. Absolute presuppositions are social, ontological, and logical bases drawing framework of a concept. Absolute presuppositions are objective and universal presuppositions rather than suppositions changing from one person to the next. Absolute presuppositions are heritages of a society and are adopted by all. Thus, absolute presuppositions are historical (Coşkun 2011: 564). And the metaphysical activity that would analyze such suppositions must be historical itself.

\section{Metaphysics as a Historical Science}

The main difference of Collingwood metaphysics from Aristotelian metaphysics is its discussion of metaphysics as a historical science. In order to explain historicity of absolute presuppositions, the author engages the discrimination between causality and law (Also see Collingwood 1998: 49). According to this, there is a distinction 
between a causal event and a law-based event. Collingwood explains this distinction by presenting examples from three different schools of physics (Newton, Kant, Einstein) (Also see Collingwood 1998: 50). In this context, while absolute presupposition of Newtonian physics is "Some events have a cause" while in Kantian thought it is "All events have causes". In Einstein physics the concept of cause disappeared and turned into "No events have causes" absolute presupposition. Moving from this transformation in absolute presuppositions, the fact that a problem is a metaphysical problem has the same meaning as its being a historical problem. The difference is that metaphysicist is not interested in information of absolute presuppositions, or their being right or wrong, good or bad. Just like an archaeologist, metaphysicist analyzes records of the thought system of that time (Collingwood 1996: 25-26-30).

\section{Result}

Reconsidering metaphysics in our time is reforming it on the basis of the autonomy of metaphysics activity. There are two basic stages of this initiative. The first one is dispelling the blur regarding metaphysics. The second one is determining the scope of metaphysics. The most important blur regarding metaphysics is failure to accept it as a historical activity. According to Collingwood, Aristotle is responsible for the failure to perceive metaphysics as a historical activity. Considering science of absolute presuppositions related to metaphysics and science of pure being could be degraded to each other initiated a thorough problem on what metaphysics is. The problem what metaphysics is gave rise to the complication of what kind of an activity its representative would be in. The way to solve this complication is to redefine coverage of metaphysical activity. 


\section{KAYNAKÇA | REFERENCES}

Aristoteles (1996). Metafizik (çev. A. Aslan). İstanbul: Sosyal Yayınlar.

Collingwood, R. G. (1996). Bir Özyaşamöyküsü (çev. A. N. Akbulut). İstanbul: Yapı Kredi Yayınları.

Collingwood, R. G. (1998). An Essay On Metaphysics. New York: Clarendon Press 0xford. Kitapevi.

Collingwood, R. G. (1999). Doğa Tasarımı (çev. K. Dinçer). Ankara: İmge

Collingwood, R. G. (2005). An Essay On Philosophical Method, New York: Clarendon Press Oxford. Yayınları.

Collingwood, R. G. (2013). Tarih Tasarımı (çev. K. Dinçer). Ankara: Doğu Batı

Collingwood, R. G. (2014). Speculum Mentis Ya Da Bilgi Haritası (çev. K. Aysevener \& Z. Eren). Ankara: Doğu Batı Yayınları.

Connelly, J. (2003). Metaphysics, Method and Politics. USA: Imprint Academic.

Coşkun, E. (2011). Robin George Collingwood. 1900'den Günümüze Büyük Düşünürler - Cilt 4 (ed. Ç. Veyssal, ss. 549-609). İstanbul: EtikYayınları.

Heimsoeth, H. (2007). Felsefenin Temel Disiplinleri (çev. T. Mengüşoğlu). Ankara: Doğu Batı Yayınları.

İyi, S. (1999). Çağımızda Metafizik Sorunu. Ankara: Ayraç Yayınevi.

Kabadayı, T. (2009). Émile Meyerson'da "İki Bilim." FLSF Felsefe ve Sosyal Bilimler Dergisi, 7, 163-172.

Kabadayı, T. (2006). Kuramdan Bağımsız Gözlem ve Deney Dili Olanaklı midır?, FLSF S. D. Ü. Felsefe Bölümü Dergisi, 2, 29-44.

Kabadayı, T. (2011). Duhem'den Laudan'a Çağdaş Bilim Felsefecileri. Ankara: Bilgesu Yayıncılık.

Kuçuradi, I. (2010). Çağın Olayları Arasında. Ankara: Türkiye Felsefe Kurumu.

Uygun, B. (2014). Çağdaş Felsefede Metafiziğin Yeniden Yorumlanması: R. G. Collingwood, (Yayımlanmamış Yüksek Lisans Tezi), Adnan Menderes Üniversitesi Sosyal Bilimler Enstitüsü, Aydın.

White, A. R. (1987). Methods of Metaphysics. London: Croom Helm. 